\title{
New host and geographic distribution of Phyllodistomum thunni (Trematoda, Gorgoderidae)
}

\author{
Gislaine Guidelli, Washington Luiz Gomes Tavechio and Beatriz Pimentel Ferreira
}

\begin{abstract}
The trematode Phyllodistomum thunni is recorded here for the first time in the marine fish Macrodon ancylodon (Perciformes, Sciaenidae), king weakfish, from the Brazilian coast, South Atlantic. The fish were caught in the region of Valença, Bahia, Brazil, between August 2009 and May 2010, to study its parasite fauna. Seventy-four fish were examined and the kidney ducts of 11 of them were found to be parasitized by this trematode. The parasite prevalence was 14.8\%; the mean intensity was 2.7 parasites per fish and the infrapopulations ranged from 1 to 5 parasites. Phyllodistomum thunni was originally described in yellowfin tuna, Thunnus albacares, from the Gulf of Guinea. Therefore, the geographic distribution and the host range of gorgoderid trematode have been expanded.
\end{abstract}

Keywords: First record, Trematode, Urinary system, Kidney ducts, Macrodon ancylodon, South Atlantic, Brazilian coast

\section{Background}

Macrodon ancylodon (Bloch \& Schneider, 1801), commonly known as the king weakfish, is a demersal sciaenid fish, with geographic distribution in South America from Venezuela to Argentina (Figueiredo and Menezes 1980). Like other sciaenids, it is commercially important, and it is one of principal species fished in Brazil (Souza et al. 2007; Castello 2010; Barros et al. 2011). According to Piorski et al. (2004), it is a generalist and carnivorous species, feeding mainly on fish and decapods.

According to Kohn et al. (2007), South American sciaenids harbor 41 species of trematodes, and some of these have been reported in up to six host species. Five species of digenetic trematodes have been recorded as parasite of the gut of M. ancylodon. These parasites are Lecithochirium microstomum (Hemiuridae), Opecoeloides polynemi (Opecoelidae), Parahemiurus merus (Hemiuridae), Pleorchis americanus (Acanthocolpidae) and Prosorhynchus osakii (Bucephalidae) registered by Sabas and Luque (2003). Kohn et al. (2007) recognized the occurrence of $P$. americanus in South American M. ancylodon.

\footnotetext{
* Correspondence: giguidelli@yahoo.com.br

Laboratório de Estudos da Ictiofauna, Centro de Ciências Agrárias,

Ambientais e Biológicas, Universidade Federal do Recôncavo da Bahia (UFRB), Rua Rui Barbosa, 710, Cruz das Almas, Bahia CEP 44380-000, Brazil
}

There are no currently published records of Gorgoderidae Looss, 1901 in king weakfish, or any other parasites of the urinary system. This study provides the first report of occurrences of parasitism by the gorgoderid trematode Phyllodistomum thunni in the kidneys of Macrodon ancylodon from coastal waters of Bahia, Brazil, South Atlantic.

\section{Methods}

Fish sampling was performed by fishermen from the region of Valença, in the coastal waters of Bahia, northeastern Brazil $\left(13^{\circ} 22^{\prime} 26^{\prime \prime} \mathrm{S}-39^{\circ} 04^{\prime} 3^{\prime \prime} \mathrm{W}\right)$ between August 2009 and May 2010, in order to survey the parasite fauna of this species. Seventy-four specimens were examined and trematodes parasitizing the kidney ducts were found. The parasites were counted, preserved in $70 \%$ alcohol, stained with Mayer's carmalumen, dehydrated in alcohol, clarified in Faia's creosote and mounted in Canada balsam. Identification was performed in accordance with Baudin-Laurencin and Richard (1973) and Campbell (2008). Voucher specimen is deposited in CHIOC (Coleção Helmintológica do Instituto Oswaldo Cruz) under number 38285. Drawing, picture and measurements were made using a Zeiss PrimoStar microscope equipped with the AxioVision software. Measurements were presented in millimeters. 


\section{Results}

Thirty trematode specimens were quantified, parasitizing the kidney ducts of eleven king weakfish, thus representing parasite prevalence of $14.8 \%$, mean intensity of 2.7 parasites per fish and infrapopulations ranging in size from 1 to 5 parasites. The trematodes belonged to the family Gorgoderidae and were identified as Phyllodistomum thunni Baudin-Laurencin \& Richard, 1973 (Fig. 1). This parasite was first described in Thunnus albacares (Bonnaterre, 1788), the yellowfin tuna, in the Gulf of Guinea.

One remarkable characteristic of the specimens examined here was its large body size (Table 1), just like the specimens described by Baudin-Laurencin and Richard. Therefore, these trematodes caused almost complete obliteration of the lumen (Fig. 2). However, P. thunni in $M$. ancylodon presented smaller size than in its type host.

\section{Conclusions}

The trematodes presented here are included in the family Gorgoderidae, because they inhabit the urinary ducts, due to the shape and arrangement of the vitellarium and simplicity of the male's terminal genitalia. This family comprises common endoparasites in the urinary systems of amphibians, reptiles, cartilaginous fish and bony fish. They can also occur, although less frequently, in the swim bladder, coelom, gut and gallbladder (Campbell 2008).

According to Campbell (2008), other characteristics that describe Gorgoderidae are smooth tegument, thin body muscles, well-developed suckers, a wide hindbody where the gonads are located, pretesticular ovary, seminal vesicle, pars prostatica and ejaculatory duct undeveloped, genital pore close to the intestinal bifurcation, uterus stretching to the hindbody, and small and nonoperculated eggs. The specimens found here were identified as Phyllodistomum according to Campbell (2008) due to the infection site, arrangement and appearance of vitellarium and gonads, adjusting to the morphological variation recognized for the genus by Ho et al. (2014). This is the most numerous genus of Gorgoderidae, with more than 100 species known from several freshwater and marine fish (Campbell 2008). According to Kohn et al. (2007), five Phyllodistomum species parasitizing eight host species in saltwater and freshwater are known in South America. A single species, Phyllodistomum sampaioi Travassos, Kohn \& Mota, 1963, has been reported parasitizing the intestine of smooth weakfish, Cynoscion leiarchus (Cuvier, 1830). Recently, new species, Phyllodistomum inecoli Razo-Mendivil, Pérez-Ponce de León \& Rubio-Godoy, 2013 and P. spinopapillatum PérezPonce de León, Pinacho-Pinacho, Mendoza-Garfia \& García-Varela, 2015, were described in the Neotropical region (Razo-Mendivil et al. 2013; Pérez-Ponce de León et al. 2015).

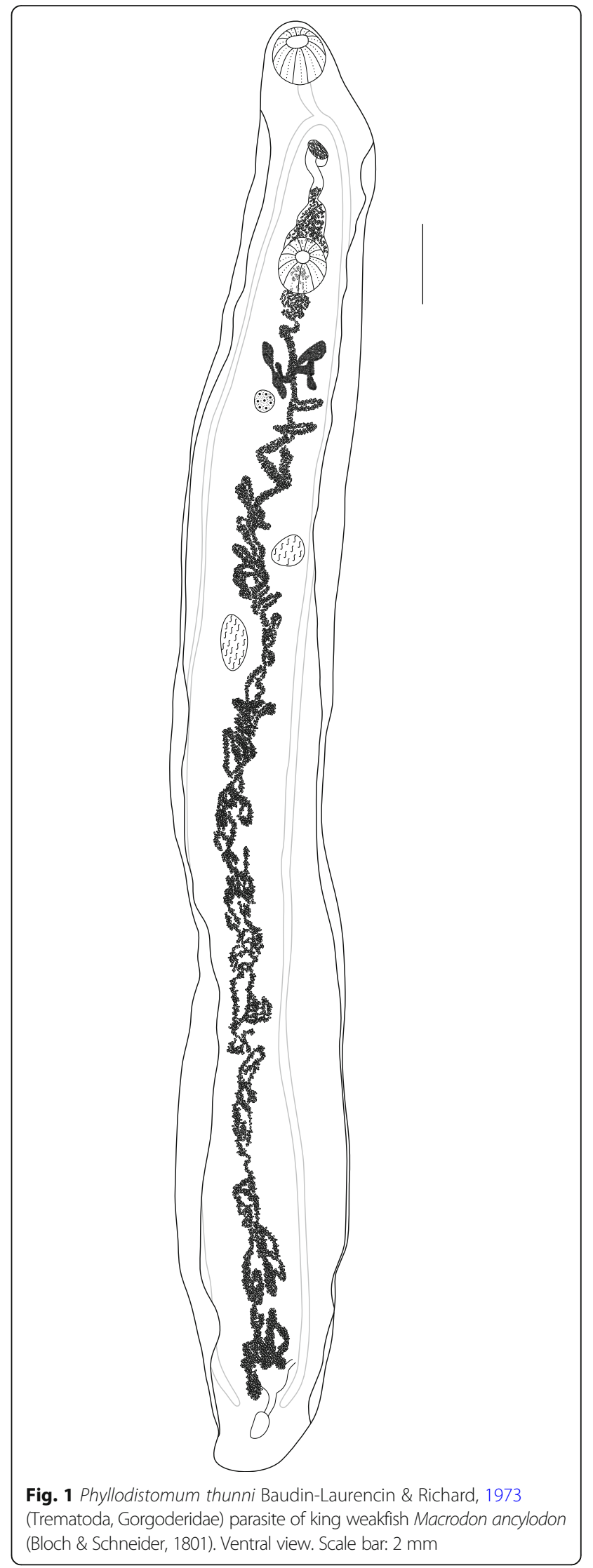


Table 1 Morphometric characteristics of Phyllodistomum thunni from its type host, Thunnus albacares, and from the new host, Macrodon ancylodon

\begin{tabular}{llllll}
\hline \multirow{2}{*}{ Character } & \multicolumn{2}{l}{ Thunnus albacares } & & & \multicolumn{2}{l}{ Macrodon ancylodon } \\
\cline { 2 - 3 } \cline { 5 - 6 } & Range & Mean & & Range & Mean \\
\hline Lenght & $15.1-28.0$ & 21.5 & & $8.96-25.04$ & 17.46 \\
Width & $2.5-6.8$ & 4.6 & & $0.54-2.49$ & 1.73 \\
Esophagus & $0.2-0.4$ & 0.3 & & $0.11-0.36$ & 0.18 \\
Oral sucker (length) & $0.8-1.4$ & 1.1 & & $0.36-0.73$ & 0.60 \\
Oral sucker (width) & $0.8-1.3$ & 1.05 & & $0.22-0.61$ & 0.50 \\
Ventral sucker (length) & $0.8-1.4$ & 1.1 & & $0.32-0.75$ & 0.54 \\
Ventral sucker (width) & $0.7-1.3$ & 1.0 & & $0.27-0.63$ & 0.47 \\
Ovary (length) & $0.6-1.0$ & 0.8 & & $0.21-0.47$ & 0.36 \\
Ovary (width) & $0.4-0.7$ & 0.8 & & $0.12-0.28$ & 0.22 \\
Left testicle (length) & $0.7-1.4$ & 1.05 & & $0.23-0.73$ & 0.48 \\
Left testicle (width) & $0.4-1.2$ & 0.8 & & $0.11-0.39$ & 0.25 \\
Right testicle (length) & $0.8-1.9$ & 1.4 & & $0.31-0.73$ & 0.62 \\
Right testicule (width) & $0.5-1.2$ & 0.8 & & $0.12-0.44$ & 0.28 \\
Egg (length) & $42-50$ & 33.5 & $40-50$ & 42.5 \\
Egg (width) & $25-28$ & 39 & $20-30$ & 22.5 \\
\hline
\end{tabular}

${ }^{a}$ Adapted from Baudin-Laurencin and Richard (1973)

According to Ho et al. (2014), 28 species of Phyllodistomum are accepted as marine. These authors suggested that three morphological groups of marine Phyllodistomum could be distinguished according to the proportions of the forebody and hindbody. Because of the notably large size of the trematodes encountered in king weakfish, they are included in the group whose representatives are clearly elongated. This group contains the species Phyllodistomum marinum (Layman, 1930), Phyllodistomum mugilis Knoff \& Amato, 1992, Phyllodistomum notosinicum Lebedev, 1970, P. sampaioi, Phyllodistomum strictum Oshmarin, 1965 and Phyllodistomum thunni Baudin-Laurencin \& Richard, 1973. Of these, only P. mugilis and P. sampaioi have previously been encountered in the Neotropical region and only P. thunni is of as large a size as the specimens in the king weakfish.

Furthermore, the trematodes found here had a smooth tegument, rounded pretesticular ovary located on the right side, intercaecal uterus, vitellarium forming two Vshaped branching units posterior the ventral sucker, oblique and post-ovarian testes, small and numerous eggs and conspicuous and subterminal excretory pore, like the trematode P. thunni described by Baudin-Laurencin and Richard (1973). This trematode was originally described in the yellowfin tuna, Thunnus albacares, in the Gulf of Guinea. Therefore, the geographical distribution of $P$. thunni has been expanded to the Neotropical region and its host range has been extended to include Macrodon ancylodon.

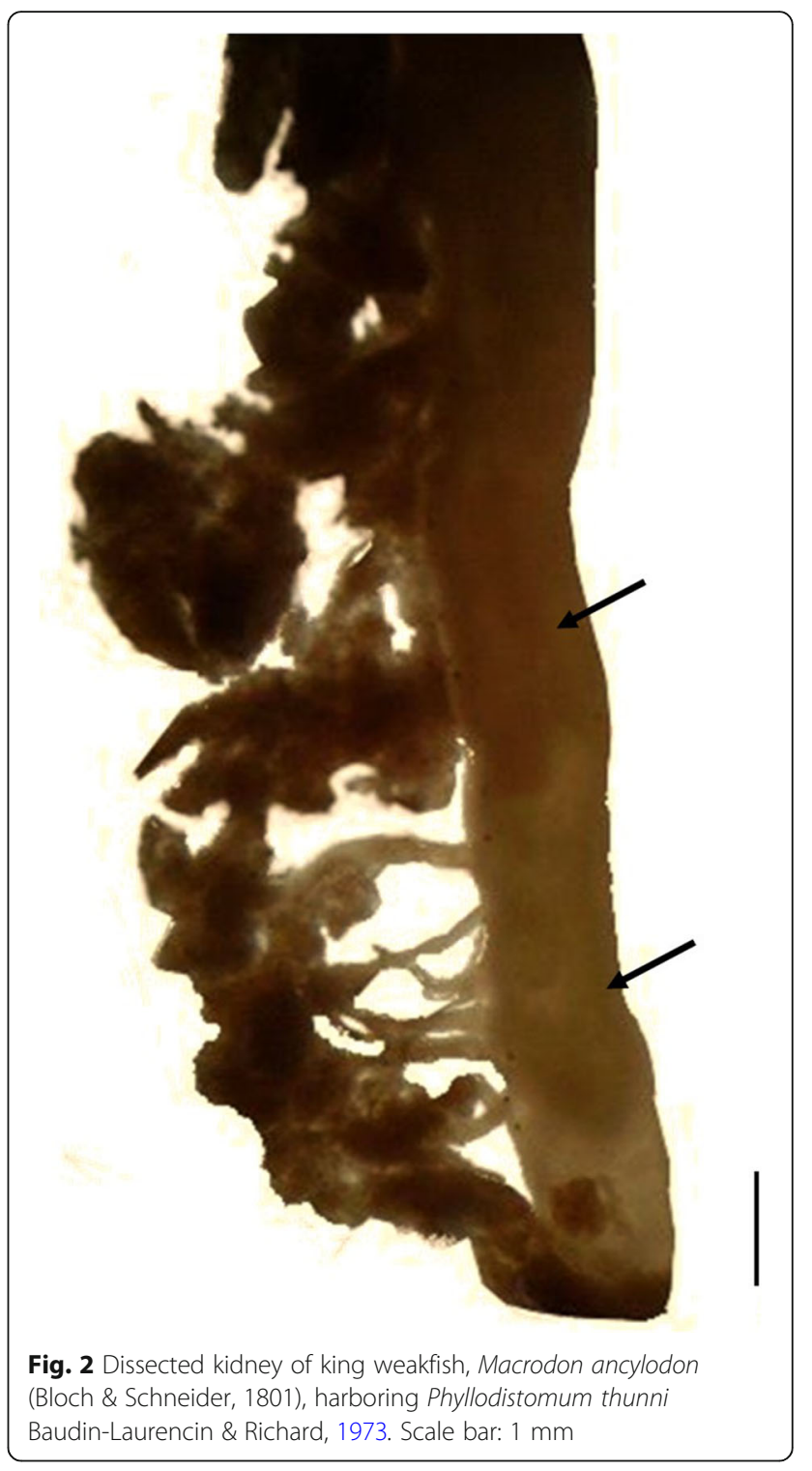

Phyllodistomum thunni occurred in M. ancylodon with prevalence slightly lower than in this type host, when studied by Baudin-Laurencin and Richard (1973). These authors encountered lower mean intensity (1.5), and up to nine specimens in one fish. Some of the weakfish also harbored several parasites, and up to five worm specimens were observed in a single fish. Thus, it can be suggested that these parasites may cause some effect on the parasitized organ, which would need to be further investigated. The parasites also presented smaller size than those from T. albacares. This can be explained through the present evidence that the specific identity of the host influences the parasite's morphological variables (Riquelme et al. 2006; González et al. 2013). In a survey on species of Opecoelidae in several fish, González et al. (2013) observed variations in parasite body length that seemed to be associated with host species sizes, such that 
longer parasites were recorded in larger fish. According to the authors, fecundity is also influenced by this variable. According to Bakke (1988), the preparation and fixation procedures also cause morphological changes.

Ho et al. (2014) reported that Phyllodistomum species show a wide range of specificity, such that most of the marine species occur in a single host species, and a few in several species and families. They also indicated that only Phyllodistomum lewisi Srivastava, 1938, Phyllodistomum mamaevi Parukhin, 1971 and Phyllodistomum thalassomum Soheir, Rabie \& Ahmed, 2000 parasitized fish from different families. With this new host record, it is demonstrated that Phyllodistomum thunni is also a marine species that infect hosts from different families that are not closely related.

\section{Acknowledgements}

We thank José dos Santos, of the Federal Institute of Education, Science and Technology of Bahia (Instituto Federal de Educação, Ciência e Tecnologia da Bahia, IFBA), Campus Valença, for his assistance in purchasing fish specimens. This research received no specific grant from any funding agency or from the commercial or not-for-profit sectors.

\section{Authors' contributions}

GG participated coordinating all phases of the work and drafting of the manuscript. WLGT acquired fish, prepared images, identified parasites and drafting of the manuscript. BPF realized fish analysis, prepared slides and identified parasites. All authors read and approved the final manuscript.

\section{Ethics approval and consent to participate}

Not applicable.

\section{Competing interests}

The authors declare that they have no competing interests.

\section{Publisher's Note}

Springer Nature remains neutral with regard to jurisdictional claims in published maps and institutional affiliations.

Received: 10 May 2016 Accepted: 27 May 2016

Published online: 28 May 2018

\section{References}

Bakke TA. Morphology of adult Phyllodistomum umblae (Fabricius) (Platyhelminthes, Gorgoderidae): the effect of preparation, killing and fixation procedures. Zool Scr. 1988;17(1):1-13.

Barros DF, Torres MF, Frédou FL. Ictiofauna do estuário de São Caetano de Odivelas e Vigia (Pará, Estuário Amazônico). Biota Neotropica. 2011;11(2):367-73.

Baudin-Laurencin F, Richard J. Phyllodistomum thunni n. Sp. (Trematoda, Gorgoderidae). Trématode parasite du thon albacore Thunnus albacares. Bulletin du Muséum National D'Histoire Naturelle. 1973;3(166):1041-4.

Campbell RA. Family Gorgoderidae Looss, 1899. In: Bray RA, Gibson DI, Jones A, editors. Keys to the Trematoda. Vol. 3. Wallinford: CABI Publishing and the Natural History Museum, Wallingford: 2008, p. 191-213.

Castello JP. O futuro da pesca e da aquicultura marinha no brasil: a pesca costeira. Ciência e Cultura. 2010;62(3):32-5.

Figueiredo JL, Menezes NA. Manual de peixes marinhos do Sudeste do Brasil: III. Teleostei (2). São Paulo: Museu de Zoologia da Universidade de São Paulo; 1980.

González MT, Henríquez V, López Z. Variations in the fecundity and body size of digenean (Opecoelidae) species parasitizing fishes from northern Chile. Rev Biol Mar Oceanogr. 2013;48(3):421-9.

Ho HW, Bray RA, Cutmore SC, Ward S, Cribb TH. Two new species of Phyllodistomum Braun, 1899 (Trematoda: Gorgoderidae Looss, 1899) from great barrier reef fishes. Zootaxa. 2014;3779(5):551-62.

Kohn A, Fernandes BMM, Cohen SC. South american trematodes parasites of fishes. Rio de Janeiro: Ministério da Saúde-FIOCRUZ; 2007.
Pérez-Ponce de León G, Pinacho-Pinacho CD, Mendoza-Garfias B, García-Varela M. Phyllodistomum spinopapillatum sp. nov. (Digenea: Gorgoderidae), from the Oaxaca killifish Profundulus balsanus (Osteichthyes: Profundulidae) in Mexico, with new host and locality records of $P$. inecoli: morphology, ultrastructure and molecular evidence. Acta Parasitol. 2015;60(2):298-307.

Piorski NM, Maranhão FRCL, Rocha RMV, Nunes JLS. Análise da estratégia alimentar de Macrodon ancylodon (Bloch \& Schneider, 1801) - (Perciformes: Sciaenidae) de um estuário do litoral ocidental do maranhão - Brasil. Boletim do Laboratório de Hidrobiologia. 2004;17:49-52.

Razo-Mendivil U, Pérez-Ponce de León G, Rubio-Godoy M. Integrative taxonomy identifies a new species of Phyllodistomum (Digenea: Gorgoderidae) from the twospot livebearer, Heterandria bimaculata (Teleostei: Poeciliidae), in Central Veracruz, Mexico. Parasitol Res. 2013;112(12):4137-50.

Riquelme C, George-Nascimento M, Balboa L. Morfometría y fecundidad de Profilicollis bullocki Mateo, Córdova \& Guzmán 1982 (Acanthocephala: Polymorphidae) en especies simpátricas de aves costeras de Chile. Rev Chil Hist Nat. 2006;79:465-74.

Sabas CSS, Luque JL. Metazoan parasites of weakfish, Cynoscion guatucupa and Macrodon ancylodon (Osteichthyes: Sciaenidae), from the coastal zone of the state of Rio de Janeiro, Brazil. Rev Bras Parasitol Vet. 2003;12(4):171-8.

Souza MR, Carneiro MH, Quirino-Duarte G, Servo GJM. Caracterização da mistura na pesca de arrasto-de-parelha desembarcada em Santos e Guarujá, São Paulo, Brasil. Bol Inst Pesca. 2007;33(1):43-51.
Submit your next manuscript to BioMed Central and we will help you at every step:

- We accept pre-submission inquiries

- Our selector tool helps you to find the most relevant journal

- We provide round the clock customer support

- Convenient online submission

- Thorough peer review

- Inclusion in PubMed and all major indexing services

- Maximum visibility for your research

Submit your manuscript at www.biomedcentral.com/submit
C Biomed Central 